\title{
Mood states and self-rated health of Brazilian jiu-jitsu fighters in competition
}

Rodrigo Batalha SILVA ${ }^{1}$, Alexandro ANDRADE*1, Guilherme Guimarães BEVILACQUA ${ }^{1}$, Adriano SCHLÖSSER ${ }^{2}$, Miguel Alencar FLORES JUNIOR ${ }^{1}$, Bianca dos Santos SEVERINO ${ }^{1}$, \& Maria Eduarda Soares RODRIGUES ${ }^{1}$

${ }^{1}$ Laboratory of Sports and Exercise Psychology - Santa Catarina State University (Brazil)

2 Psychology Department - University of West Santa Catarina (Brazil)

8th IMACSSS International Conference Abstracts, Viseu (Portugal), October 10-12, 2019

Type: Poster presentation

\section{Abstract}

Brazilian Jiu-Jitsu (BJJ) athletes are subjected to a large and intensive training load that may cause injuries. These injuries can be detrimental to the physical and mental health of these athletes. In this regard, the aim of this study was to compare the self-reported health and mood states of BJJ athletes. Twenty-three BJJ athletes participated in the study. A questionnaire was used for general characterization of the athletes, which included the self-rated health question, and the Brunel Mood Scale - BRUMS were used. The mood profile was similar to the Iceberg profile. Athletes with regular health had lower vigor than athletes with excellent vigor. Lower vigor in athletes who reported regular health may be related to concern about injury. Specific strength training and careful execution of the technique should be emphasized in training.

Keywords: Martial arts; combat sports; BJJ; sport psychology; injury.

\section{Introduction}

In sports, it is known that for an athlete to be successful, training and high levels of physical fitness are required, involving various physical abilities such as strength, power, agility, flexibility, among others (Andreato, Lara, Andrade, \& Branco, 2017). To improve physical abilities, Brazilian jiu-jitsu (BJJ) athletes may be subjected to extensive hours of training, suffering a heavy emotional overload due to the physical danger to which they are subjected (Branco et al., 2016; Coswig, Neves, \& Del Vecchio, 2013). Among the dangers to the health of these athletes, BJJ athlete is exposed to a high risk of injuries resulting from falls, overexertion or joint locks are the most common in training and competition (Silva Júnior, Kons, Dellagrana, \& Detanico, 2018). Injured athletes may demonstrate poorer quality of life and health and may also affect aspects beyond the physical component of heatlh (Valovich McLeod, Bay, Parsons, Sauers, \& Snyder, 2009). Another aspect to be highlighted the practice of weight loss before competitions. Common among fighters, it can affect performance, endanger the fighter's health, (Oppliger, Case, Horswill, Landry, \& Shelter, 1996) as well as negatively affect the fighter's psychological state. (Franchini et al., 2006). Lucena et al., (2009) found that only 7\% of athletes reported feeling good about rapid weight loss, while the others reported negative sensations such as uneasiness, apprehension, feelings of emotional upheaval. In this sense, mood states are shown as a variable that reflects feelings, thoughts, and degree of enthusiasm in performing tasks emotional as well as bodily, and behavioral states (Lane $\&$ Terry, 2000). Mood can vary in durations and intensity and involves six factors; five are negative (tension, depression, anger, fatigue, and confusion), and one is positive (vigor) (Rohlfs et al., 2008). The literature indicates that the near-ideal mood profile for better athletic performance is characterized by higher vigor in relation to the other factors. This is called the Iceberg Profile (Morgan, 1980). Mood states have received attention in recent combat sports research to assess the

\footnotetext{
*Email: alexandro.andrade.phd@gmail.com
} 
psychological state and mental health of athletes (Andrade, Silva, Flores Junior, Rosa, \& Dominski, 2019; Hernández, Torres-Luque, \& Olmedilla, 2009; Wong, Thung, \& Pieter, 2006).

\section{Objectives} athletes.

The aim of this study was to compare the self-reported health and mood states of BJJ

\section{Methodology}

Twenty three BJJ male athletes of from the Santa Catarina state (Brazil) participated in the study. The participants average age was 27.79 years, ranging from ages 18 to 46 ( \pm 6.97 ), with a mean height of $176 \mathrm{~cm} \mathrm{(} \pm 0.08)$, an average weight of $83.1 \mathrm{~kg}( \pm 14.59)$, and an average of 6,13 years of BJJ practice. Among these athletes, $5(21,7 \%)$ compete at a regional level, $16(69.6 \%)$ at a national level, and $7(8,7 \%)$ at an international level.

A questionnaire was used for general characterization of the athletes, which included the self-rated health question (How do you self-rate your health?), with a response ranging from 0 (terrible) to 4 (excellent). The Brunel Mood Scale - BRUMS (Rohlfs et al., 2008) was used to verify the athletes' mood states. Data collection was done on the same day of the competition, before official weigh-in, in a quiet and reserved place. Data was treated using descriptive and inferential statistics trough SPSS software version 20.0.

Descriptive statistics were used, and data is presented in percentage and standard variation. For inferential statistics, Shapiro-Wilk test was used to verify data normality. In order to compare the mood states and health of BJJ athletes, was used the ANOVA one-way for the parametric data and the Mann-Whitney $U$ test for the non parametric data. A level of significance of $p<0.05$ was settled. This study was approved by the Committee for Ethics in Human Research of the Santa Catarina State University under protocol 2.776 .490$.

\section{Results}

The profile of mood states of the BJJ athletes was similar to the iceberg profile, with moderate levels of tension. Concerning self-rated health, $21.7 \%$ of athletes reported regular health, $52.2 \%$ had good health and $26.1 \%$ had excellent health. Comparing mood with self-rated health, it was found that athletes with regular health have worse vigor compared to athletes with excellent health at a pre-competitive time. $(\mathrm{p}<.05)$ (Table 1$)$.

Table 1. Mood Profile Comparison of BJJ Athletes with Different Health Ratings.

\begin{tabular}{|c|c|c|c|c|c|c|c|c|c|c|c|c|}
\hline & \multicolumn{2}{|c|}{ Tension } & \multicolumn{2}{|c|}{ Depression } & \multicolumn{2}{|c|}{ Anger } & \multicolumn{2}{|c|}{ Vigor } & \multicolumn{2}{|c|}{ Fatigue } & \multicolumn{2}{|c|}{ Confusion } \\
\hline & $\bar{x}$ & \pm & $\bar{x}$ & \pm & $\bar{x}$ & \pm & $\bar{x}$ & \pm & $\bar{x}$ & \pm & $\bar{x}$ & \pm \\
\hline $\begin{array}{l}\text { General }(n=23) \\
\text { Health }\end{array}$ & 5.04 & 3.64 & 0.96 & 1.58 & 2.13 & 3,48 & 10.96 & 2.77 & 3.39 & 2.72 & 2.7 & 2.68 \\
\hline Regular $(n=5)$ & 6.6 & 4.82 & 0,8 & 1,78 & 3 & 5.65 & $9,4^{*}$ & 2.79 & 3 & 2,12 & 4.4 & 3.36 \\
\hline Good $(n=12)$ & 4.5 & 3.37 & 1,08 & 1.62 & 1,67 & 2,87 & 10,42 & 2.35 & 3.83 & 3,04 & 2.5 & 2.71 \\
\hline Excellent $(n=6)$ & 4.83 & 3.43 & 0,83 & 1.6 & 2.33 & 2,87 & 13.33* & 2.33 & 2.83 & 2.78 & 1.67 & 1.5 \\
\hline
\end{tabular}

$\bar{x}=$ mean; $\pm=$ standard deviation; ${ }^{*}=\mathrm{p}<.05$

\section{Discussion}

The athletes' mood profile in this study was similar to other studies with BBJ athletes (Andrade et al., 2019; Brandt, 2015), presenting high vigor, moderate tension and low depression, fatigue, confusion and anger in the precompetitive period. That would be close to the ideal profile for athletes to achieve the best performance (Terry, Lane, \& Fogarty, 2003). Attention should be given to high tension, as it can generate musculoskeletal tension that may be related to the incidence of injuries due to low physical and mental capacity (Andrade, Bevilacqua, Coimbra, Pereira, \& Brandt, 2016).

Lower vigor in athletes who reported regular health may be related to concern about injury. In mixed martial arts, an injured athlete cannot train and compete at a high level, making this one of 
their main fears in combat sports. (Vaccaro, Schrock, \& McCabe, 2011). Considering the incidence of injuries in BJJ, it is questioned that the practice of hurting your opponent until he or she is unconscious and forcing joints to almost rupture bones or ligaments, can be detrimental to the physical and mental health of athletes and practitioners who choose combat sports as physical activity (White, 2007).

\section{Conclusion}

In this study, it was found that BJJ athletes who had regular health had worse vigor than athletes with excellent health. The large training load and the danger that the sport poses in the mood and health of athletes can generate important psychological changes in these athletes. Thus, specific strength training programs for injury prevention are suggested, as well as care in the execution of techniques during training, aiming at reducing the possibility of injury.

\section{References}

Andrade, A., Bevilacqua, G. G., Coimbra, D. R., Pereira, F. S., \& Brandt, R. (2016). Sleep quality, mood and performance: A study of elite Brazilian volleyball athletes. Journal of Sports Science and Medicine, 15(4), 601-605.

Andrade, A., Silva, R. B., Flores Junior, M. A., Rosa, C. B., \& Dominski, F. H. (2019). Changes in mood states of Brazilian jiu-jitsu athletes during training and competition. Sport Sciences for Health, 15(2), 469-475. doi: 10.1007/s11332-019-00562-0

Andreato, L. V., Lara, F. J. D., Andrade, A., \& Branco, B. H. M. (2017). Physical and Physiological Profiles of Brazilian Jiu-Jitsu Athletes: a Systematic Review. Sports Medicine - Open, 3(1), 9. doi: 10.1186/s40798-016-0069-5

Branco, B. H. M., Andreato, L. V., Mendes, A. A., Gilio, G. R., Andrade, A., \& Júnior, N. N. (2016). Effects of a Brazilian jiu-jitsu training session on physiological, biochemical, hormonal and perceptive responses. Archives of Budo Science of Martial Arts and Extreme Sports, 12(0).

Brandt, R. (2015). Humor Pré-Competitivo Em Atletas Brasileiros De Jiu Jitsu. Caderno de Educação Física e Esporte, Marechal Cândido Rondon., 13(1), 21-30.

Coswig, V. S., Neves, A. H. S., \& Del Vecchio, F. B. (2013). Efeitos do tempo de prática nos parâmetros bioquímicos, hormonais e hematológicos de praticantes de jiu-jitsu brasileiro: Efectos del tiempo de práctica en los parámetros bioquímicos, hormonales y hematológicos de practicantes de jiu-jitsu brasileño. Revista Andaluza de Medicina Del Deporte, 6(1), 17-23. doi: 10.1016/S1888-7546(13)70030-3

Franchini, E., Herbert, A., Junior, L., Peso, P. D. E., Esportes, E. M., \& Domínio, D. E. C. D. E. (2006). Weight loss in grappling combat sports: review and applied. Revista Brasileira de Cineantropometria e Desempenho Humano, 8(2), 92-101.

Hernández, R., Torres-Luque, G., \& Olmedilla, A. (2009). Relations among Training Volume, Body Weight, and Profile of Mood States for Elite Judoka during a Competitive Period. Perceptual and Motor Skills, 109(3), 870-880. doi: 10.2466/pms.109.3.870-880

Lane, A. m., \& Terry, P. c. (2000). The nature of mood: development of a conceptual model with a focus on depression. Journal of Applied Sport Psychology, 12(1), 16-33.

Lucena, M., Miranda, E., Asano, R., Bartholomeu Neto, J., \& Silva, J. (2009). Métodos e estratégias utilizadas para perda de peso pré-competição em lutadores de boxe. Revista Brasileira de Nutriçao Esportiva, 3(13), 6.

Morgan, P. (1980). No Title. In W. F. Straub (Ed.), Sport psychology: An analysis of athlete behavior (1st ed., pp. 330-339). Ithaca, NY: Mouvement.

Oppliger, R. A., Case, H. S., Horswill, C. A., Landry, G. L., \& Shelter, A. C. (1996). American College of Sports Medicine position stand. Weight loss in wrestlers. Medicine and Science in Sports and Exercise, 28(6), ix-xii.

Rohlfs, I. C. P. de M., Rotta, T. M., Luft, C. D. B., Andrade, A., Krebs, R. J., \& Carvalho, T. de. (2008). A Escala de Humor de Brunel (Brums): instrumento para detecção precoce da síndrome do excesso de treinamento. Revista Brasileira de Medicina Do Esporte, 14(3), 176-181. doi: 10.1590/S1517-86922008000300003

Silva Júnior, J. N. da, Kons, R. L., Dellagrana, R. A., \& Detanico, D. (2018). Prevalência de lesões em atletas de Brazilian jiu-jitsu: comparação entre diferentes níveis competitivos. Brazilian

Rev. Artes Marciales Asiát., 14(2s), 43-46 2019 
Journal of Kinanthropometry and Human Performance, 20(3), 280-289. doi: 10.5007/19800037.2018v20n3p280

Terry, P. C., Lane, A. M., \& Fogarty, G. J. (2003). Construct validity of the Profile of Mood States Adolescents for use with adults. Psychology of Sport and Exercise, 4(2), 125-139. doi: 10.1016/S1469-0292(01)00035-8

Vaccaro, C. A., Schrock, D. P., \& McCabe, J. M. (2011). Managing emotional manhood: Fighting and fostering fear in mixed martial arts. Social Psychology Quarterly. doi: $10.1177 / 0190272511415554$

Valovich McLeod, T. C., Bay, R. C., Parsons, J. T., Sauers, E. L., \& Snyder, A. R. (2009). Recent Injury and Health-Related Quality of Life in Adolescent Athletes. Journal of Athletic Training, 44(6), 603-610. doi: 10.4085/1062-6050-44.6.603

White, C. (2007). Mixed martial arts and boxing should be banned, says BMA. BMJ (Clinical Research Ed.), 335(7618), 469. doi: 10.1136/bmj.39328.674711.DB

Wong, R. S. K., Thung, J. S., \& Pieter, W. (2006). Mood and performance in young malaysian karateka. Journal of Sports Science \& Medicine, 5(CSSI), 54-59. 